\title{
Studi Pemanfaatan Prekursor Fly Ash Lokal pada Self Compacting Geopolymer Concrete (SCGC)
}

(Study on the Utilization of Local Fly Ash Precursor on Self Compacting Geopolymer Concrete (SCGC))

\author{
EVELYN ANABELA ANISA, RAHMAD AFRIANSYA, JULIAN RANDISYAH, \\ PINTA ASTUTI
}

\begin{abstract}
ABSTRAK
Beton merupakan suatu material yang banyak digunakan dalam dunia konstruksi. Namun, setiap produksi beton menimbulkan dampak buruk pada pemanasan global. Semen sebagai bahan pengikat beton dapat menyumbang emisi $\mathrm{CO}_{2}$ sebanyak $8 \%$ dalam setiap produksinya. Proses pengecoran pada beton juga dapat menghasilkan polusi suara akibat penggunaan alat vibrator. Para peneliti terus berupaya menghasilkan beton yang lebih ramah lingkungan. Self Compacting Geopolymer Concrete (SCGC) merupakan kombinasi baru antara beton geopolimer dan Self Compacting Concrete (SCC) yang masih terus diteliti dan dikembangkan hingga saat ini. SCGC merupakan beton ramah lingkungan karena tidak menggunakan semen portland sebagai bahan pengikatnya. Penggunaan beton SCGC tidak memerlukan vibrator karena memiliki sifat flowability yang baik. Penelitian ini menggunakan bahan pengikat berupa material pozzolan yang mengandung senyawa kimia berupa $\mathrm{SiO}_{2}$ dan $\mathrm{Al}_{2} \mathrm{O}_{3}$. Tahapan penelitian ini dilakukan dengan mencari metode curing dan mix design optimal dalam penyusunan SCGC. Pengujian XRF perlu dilakukan dalam penelitian ini untuk mengetahui kandungan senyawa kimia pada fly ash Tjiwi Kimia. Beberapa pengujian beton segar SCGC diperoleh hasil berupa slump flow $690 \mathrm{~mm}$, T50 2,4 detik, $v$-funnel 8,35 mm, dan rasio $l$ box 0,84 . Sifat mekanik beton diuji berdasarkan kuat tekan, kuat tarik belah, dan kuat lentur dengan hasil rata-rata sebesar 27,05 $\mathrm{MPa}, 6,32 \mathrm{MPa}, 1,91 \mathrm{MPa}$.
\end{abstract}

Kata Kunci: Self Compacting Geopolymer Concrete, Fly Ash, Prekursor, Flowability, Sifat Mekanik.

\section{ABSTRACT}

Concrete is a material that is widely used in the construction world. The production of concrete has an impact on global warming. Cement as a binder influenced $8 \%$ of $\mathrm{CO}_{2}$ in its production. Concrete casting will produce noise pollution caused by the concrete vibrator. Researchers have made efforts to produce green concrete. Self Compacting Geopolymer Concrete (SCGC) is a new combination of Self Compacting Concrete (SCC) and geopolymer concrete. SCGC is an eco-friendly material because it does not use portland cement and this concrete application does not require a vibrator due to its flowability. In this study, the binder used is local pozzolanic materials which contain $\mathrm{SiO}_{2}$ and $\mathrm{Al}_{2} \mathrm{O}_{3}$. This research stage is carried out by finding the optimal curing method and mix design in the preparation of SCGC.XRF testing to be done in this study to determine the content of chemical compounds in Tjiwi Kimia fly ash. Several tests of SCGC fresh concrete were obtained in the form of slump flow $690 \mathrm{~mm}$, T50 2.4 seconds, v-funnel 8.35 $\mathrm{mm}$, and l-box ratio 0.84. The mechanical properties of concrete will be tested based on compressive, split tensile, and flexural strength with the average results of $27.05 \mathrm{MPa}$, 6.2 MPa, 1.91 MPa.

Keywords: Self Compacting Geopolymer Concrete, Fly Ash, Precursor, Flowability, Mechanical Properties. 


\section{PENDAHULUAN}

Beton merupakan konstruksi yang banyak dibutuhkan masyarakat global karena ketersediaan bahan baku dan kemudahan dalam pembentukannya (Gulsan dkk, 2019). Bahan pengikat utama yang digunakan dalam pembuatan beton adalah semen. Hasil kajian Chatam House (2018), melaporkan industri semen memproduksi sekitar $8 \%$ dari emisi $\mathrm{CO}_{2}$ global. Sementara, produksi semen dunia diperkirakan meningkat 3,27 miliar ton dari tahun 2010 menjadi 4,83 miliar ton pada tahun 2030 (Ardiantoro dkk, 2021). Proses manufaktur semen menjadi penyumbang utama emisi gas rumah kaca yang dilepaskan selama pembuatannya. Faktanya, pada setiap satu ton produksi semen menghasilkan 0,87 ton $\mathrm{CO}_{2}$ (Elahi dkk, 2020). Di sisi lain, dampak negatif dari beton konvensional adalah penggunaan alat vibrator saat pengecoran, sehingga menimbulkan kebisingan yang mempengaruhi polusi suara. Para ahli konstruksi masih berupaya untuk memproduksi beton yang lebih ramah lingkungan, seperti Self Compacting Geopolymer Concrete (SCGC). Pada bidang perbaikan struktur beton, juga dibutuhkan geopolymer sebagai repair material khusus untuk rehabilitasi struktur beton dengan tulangan terkorosi menggunakan metode anoda korban (Astuti dkk, 2018, Astuti dkk, 2019, Kamarulzaman dkk, 2019, Astuti dkk, 2020 dan Astuti dkk, 2021).
Self Compacting Geopolymer Concrete (SCGC) merupakan beton inovatif dengan kombinasi baru antara self compacting concrete dan geopolymer concrete yang masih terus dikembangkan penelitiannya. SCGC merupakan material eco-friendly karena tidak menggunakan semen sebagai bahan pengikatnya seperti pada beton konvensional. SCGC dapat dianggap sebagai bahan konstruksi yang canggih dan inovatif karena tidak memerlukan upaya pemadatan akibat kemampuan mengalirnya (flowability) yang tinggi (Praveen dan Srinivasan, 2017). Pembuatan SCGC tidak memerlukan jumlah tenaga kerja yang banyak dalam melakukan pemadatannya karena memiliki sifat flowability. Salah satu persyaratan dari SCGC bersumber pada EFNARC 2002 dari persyaratan SCC yang meliputi filling ability, passing ability, dan segregation resistance. SCGC diproduksi dengan mengaktifkan alumino-silicate ( $\mathrm{Si}-\mathrm{Al}$ ) pada prekursor dengan alkali aktivator $\left(\mathrm{NaOH}\right.$ dan $\left.\mathrm{Na}_{2} \mathrm{SiO}_{3}\right)$ (Vinothkumar dkk, 2019). Prekursor yang sering digunakan dalam beberapa penelitian adalah fly ash. Pemanfaatan fly ash di Indonesia telah terangkum pada Gambar 1. v Produksi FA

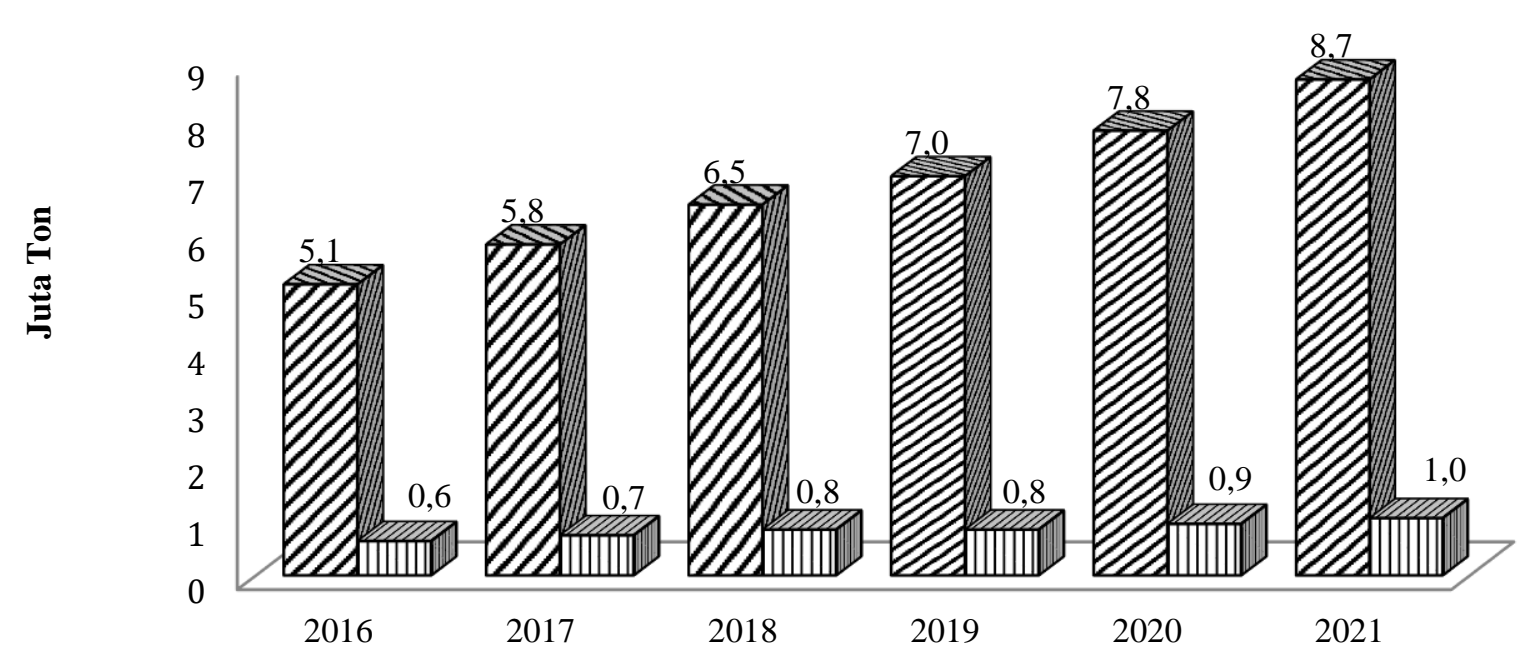

Tahun

GAMbAR 1. Produksi dan Pemanfaatan Fly Ash di Indonesia (Sumber: Ekaputri dan Bari, 2020) 
Abu terbang batu bara (fly ash) adalah salah satu limbah yang dihasilkan dari proses pembakaran batu bara. Ketersediaan fly ash memiliki jumlah yang melimpah di Indonesia. Berdasarkan PP RI No 101 tahun 2014, fly ash termasuk dalam kategori limbah bahan berbahaya dan beracun (B3) kategori dua. Hal tersebut berakibat pada pemanfaatan fly ash harus melalui perizinan dari Kementerian Lingkungan Hidup dan Kehutanan (KLHK), sehingga pemanfaatan fly ash di Indonesia hanya 10-12\% (Ekaputri dkk, 2019).

Apabila pemanfaatan fly ash terhambat, maka pada tahun 2027 akan terjadi penumpukan fly ash yang tidak terkendali mencapai 10,4 juta ton setiap tahun (Ekaputri dan Bari, 2020). Pada tahun 2021, limbah abu terbang batu bara (fly ash) telah dikeluarkan dari kategori limbah B3 (PP RI no 22 tahun 2021). Hal tersebut memudahkan para pelaku industri dan peneliti dalam memanfaatkan limbah tersebut secara optimal.

Selain fly ash, bahan campuran lain dalam pembuatan SCGC adalah alkali aktivator berupa $\mathrm{NaOH}$ dan $\mathrm{Na}_{2} \mathrm{SiO}_{3}$. Natrium hidroksida $(\mathrm{NaOH})$ dan natrium silikat $\left(\mathrm{Na}_{2} \mathrm{SiO}_{3}\right)$ pada SCGC digunakan sebagai aktivator (pengaktif reaksi) dan katalisator (pemercepat reaksi) pada beton tersebut. Molaritas $\mathrm{NaOH}$ juga dapat berpengaruh pada kekuatan SCGC. Semakin tinggi molaritas yang diberikan, maka kekuatan yang dihasilkan juga akan semakin besar (Memon dkk, 2013). Huseien dkk (2018) telah melakukan pengkajian pengaruh molaritasi $\mathrm{NaOH}$ dengan variasi 2,4,6,8,10,12,14 dan 16 M. Berdasarkan hasil, disimpulkan bahwa molaritas $12 \mathrm{M}$ memiliki proporsi yang optimum untuk meningkatkan kuat tekan beton.

Penggunaan superplasticizer menyebabkan kemampuan mengalir (flowability) pada beton segar dapat memiliki kontrol yang lebih baik terhadap SCGC, sehingga akan meningkatkan workabilitas pada fresh concrete SCGC (Rawi dan Taysi, 2018). Reddy dan Kumar (2017), telah melakukan penelitian mengenai SCGC menggunakan fly ash dengan variasi $100 \%$. Rasio $\mathrm{NaOH} / \mathrm{Na}_{2} \mathrm{SiO}_{3}$ pada penelitian tersebut adalah 1:1 dengan tambahan superplasticizer sebesar $1 \%$ dari berat bahan pengikat (binder). Hasil pengujian fresh concrete yang dilakukan berupa slump flow test, T-50, v-funnel dan l-box telah memenuhi syarat EFNARC 2002.

Afriansya dkk (2021), menjelaskan bahwa kandungan kimia pada prekursor dalam geopolimer dapat mempengaruhi kualitas dari beton tersebut. Pengaruh geopolimer juga dapat ditentukan berdasarkan bahan dan perawatan (curing) yang digunakan. Berdasarkan beberapa literatur, metode perawatan (curing) pada SCGC dilakukan dengan 2 tahap, yaitu curing oven dan curing suhu ruangan (Vinothkumar dkk, 2019). Patel dan Shah (2018), telah menguji penggunaan fly ash sebagai binder SCGC dengan metode curing berbeda. Hasil pengujian disimpulkan bahwa metode curing dengan temperatur suhu $70^{\circ} \mathrm{C}$ memiliki hasil yang paling optimal dibandingkan suhu $60^{\circ} \mathrm{C}$ apabila ditambah dengan perlakuan curing suhu ruangan pada umur 28 hari terhadap pengujian kuat tekan, kuat tarik belah dan kuat lentur. Perlakuan curing pada suhu tinggi dinilai cukup efektif dalam mempercepat proses polimerisasi yang berpengaruh terhadap kekuatan SCGC. Berdasarkan rekomendasi dari beberapa literatur, maka pada penelitian ini akan menggunakan proporsi SCGC dengan rasio $\mathrm{NaOH} / \mathrm{Na}_{2} \mathrm{SiO}_{3}$ sebesar 1:1 dan molaritas $\mathrm{NaOH} 12$ M. Selanjutnya metode curing menggunakan suhu $70^{\circ} \mathrm{C}$ supaya memperoleh hasil kekuatan yang optimal.

Penelitian tersebut dilakukan dengan mengaplikasikan beton ramah lingkungan yang kuat, cepat, serta ekonomis. Inovasi beton tersebut diperoleh dengan mengombinasikan dua teknologi beton, yaitu beton SCC (self compacting concrete) dan beton geopolimer. Diharapkan inovasi dari perpaduan dua jenis beton tersebut dapat mendukung respon perubahan di masa depan seiring dengan meningkatnya pembangunan konstruksi. Pada penelitian ini akan digunakan studi eksperimental dengan mengkaji material limbah pozzolan berupa abu terbang batu bara (fly ash) $100 \%$ untuk menggantikan bahan pengikat dari semen konvensional sebagai dasar penelitian.

\section{METODE PENELITIAN}

\section{Penggunaan Material}

Prekursor pada penelitian ini berupa fly ash yang berasal dari limbah pembakaran PT. Tjiwi Kimia. Abu terbang batu bara (fly ash) pada PT. Tjiwi Kimia memiliki berat jenis sebesar 2,53. Berdasarkan ASTM C618, fly ash tersebut termasuk dalam kategori high calcium fly ash 
dengan kandungan $\mathrm{CaO}>10 \%$. Kandungan senyawa kimia pada fly ash PT Tjiwi Kimia telah dilakukan uji $x$-ray fluorescence (XRF) yang dirangkum pada Tabel 1.

Penelitian ini menggunakan dua jenis agregat, yaitu agregat halus dan agregat kasar. Penelitian ini menggunakan agregat dalam kondisi Saturated Surfaced Dry (SSD). Agregat halus berasal dari pasir Progo, sedangkan agregat kasar berasal dari kerikil Clereng. Kerikil Clereng yang digunakan memiliki ukuran $>12,5 \mathrm{~mm}$, sehingga ukuran tersebut dapat meningkatkan workability pada beton. Agregat halus telah diuji dengan hasil yang terangkum dalam Tabel 2, sedangkan agregat kasar telah ditabulasikan pada Tabel 3 .

Alkali aktivator yang digunakan berupa natrium silikat $\left(\mathrm{Na}_{2} \mathrm{SiO}_{3}\right)$ dan natrium hidroksida $(\mathrm{NaOH})$. Alkali aktivator memiliki peran dalam reaksi polimerisasi dalam SCGC. $\mathrm{NaOH}$ berfungsi untuk mengaktifkan reaksi aluminosilicate (Al-Si), sedangkan $\mathrm{Na}_{2} \mathrm{SiO}_{3}$ berperan sebagai katalisator untuk mempercepat reaksi polimerisasi pada SCGC. Rasio $\mathrm{NaOH} / \mathrm{Na}_{2} \mathrm{SiO}_{3}$ yang digunakan sebesar 1:1 dengan konsentrasi $\mathrm{NaOH} 12 \mathrm{M}$. Pembuatan $12 \mathrm{M} \mathrm{NaOH}$ dilakukan dengan cara mencampurkan 400 gram $\mathrm{NaOH}$ dan 1 liter aquades. Larutan $\mathrm{NaOH} 12 \mathrm{M}$ harus dipersiapkan 1 hari sebelum pembuatan beton berlangsung.

Superplasticizer pada penelitian ini menggunakan Sika ViscoCrete-8670MN untuk meningkatkan workability dari beton segar SCGC. Sementara kadar superplasticizer yang digunakan dalam mix design sebesar $2 \%$ dari prekursor. Penggunaan $2 \%$ pada penelitian ini mengacu pada peraturan batas maksimal dari penggunaan Sika ViscoCrete-8670MN.

TABEL 1. Hasil Pengujian XRF Pada Fly Ash

\begin{tabular}{cc}
\hline Kandungan Senyawa & Komposisi (\%) \\
\hline $\mathrm{SiO}_{2}$ & 32 \\
$\mathrm{Al}_{2} \mathrm{O}_{3}$ & 13 \\
$\mathrm{Fe}_{2} \mathrm{O}_{3}$ & 27 \\
$\mathrm{CaO}$ & 19,5 \\
$\mathrm{~K}_{2} \mathrm{O}$ & 2,48 \\
$\mathrm{MnO}$ & 0,28 \\
$\mathrm{TiO}_{2}$ & 1,52 \\
$\mathrm{NiO}$ & 0,03 \\
$\mathrm{CuO}$ & 0,05 \\
$\mathrm{SrO}$ & 0,97 \\
$\mathrm{BaO}$ & 0,33 \\
\hline
\end{tabular}

TABel 2. Data Agregat Halus

\begin{tabular}{cc}
\hline Standar Pengujian & Agregat Halus \\
\hline Berat Jenis & 2,5 \\
Modulus Halus Butir & $2,2 \%$ \\
Kadar Air & $3,0 \%$ \\
Kadar Lumpur & $2,1 \%$ \\
\hline
\end{tabular}

TABEL 3. Data Agregat Kasar

\begin{tabular}{cc}
\hline Standar Pengujian & Agregat Kasar \\
\hline Berat Jenis & 2,6 \\
Kadar Lumpur & $1 \%$ \\
Kehausan & $30 \%$ \\
\hline
\end{tabular}


Pencetakan dan Perawatan

Cetakan yang digunakan berupa silinder berukuran 7,5 $\mathrm{mm}$ x $15 \mathrm{~mm}$ untuk pengujian kuat tekan dan kuat tarik. Penelitian ini menggunakan cetakan balok berukuran $10 \mathrm{~mm}$ x $10 \mathrm{~mm}$ x $700 \mathrm{~mm}$ untuk pengujian kuat lentur.

Setiap cetakan akan diisi dengan beton segar tanpa dilakukan pemadatan manual karena keunggulan SCGC yang memiliki sifat dapat mengalir dengan sendirinya (flowability) dengan baik. Setelah campuran didiamkan dalam cetakan selama 24 jam, seluruh spesimen akan dilakukan perawatan (curing) suhu $70^{\circ} \mathrm{C}$ dalam oven selama 1 hari, seperti yang tertera pada Gambar 2(a). Setelah itu, seluruh spesimen akan dilakukan curing dalam suhu ruangan dengan dibungkus plastic wrapped hingga usia pengujian selama 28 hari. Perlakuan tersebut dapat dicermati pada Gambar 2(b).

\section{Mix Design}

Proporsi yang digunakan dalam pembuatan self compacting geopolymer concrete (SCGC) telah terangkum dalam Tabel 4.

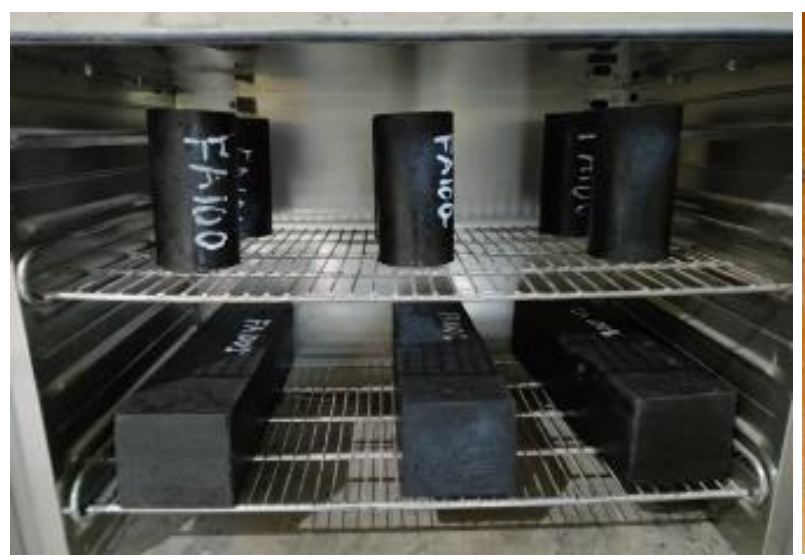

(a)

\section{HASIL DAN PEMBAHASAN}

\section{Pengujian Beton Segar}

Penelitian ini menggunakan prekursor fly ash $100 \%$ dengan komposisi $500 \mathrm{~kg} / \mathrm{m}^{3}$. Penggunaan fly ash pada campuran beton dapat meningkatkan kemudahan dalam pengerjaan (workability), hal ini dikarenakan bentuk partikel abu terbang batubara yang bulat dan halus (Paramitha dkk, 2017). Penambahan superplasticizer sebesar $2 \%$ dari berat prekursor efektif untuk meningkatkan flowability pada SCGC. Berdasarkan hasil penelitian diperoleh nilai slump flow sebesar $690 \mathrm{~mm}$, T50 terjadi selama 2,4 detik, hasil $v$ funnel test sebesar $8,35 \mathrm{~mm}$ dan rasio l-box yang didapatkan sebesar 0,84 . Hasil tersebut dapat diketahui berdasarkan kriteria pada pengujian beton segar berupa slump flow test, T50, v-funnel, dan l-box test berdasarkan spesifikasi EFNARC 2002. Berdasarkan hasil dapat diperoleh kesimpulan bahwa, seluruh hasil pengujian beton segar telah memenuhi kriteria standar EFNARC 2002. Hasil pengujian beton segar telah terangkum dalam Tabel 5.

GAMBAR 2. (a) Curing oven $\left(70^{\circ} \mathrm{C}\right)$, (b) Curing suhu ruang (wrapping plastic)

TABEL 4. Komposisi SCGC

\begin{tabular}{|c|c|}
\hline Material & Komposisi $\left(\mathrm{kg} / \mathrm{m}^{3}\right)$ \\
\hline Fly ash & 500 \\
\hline Agregat Kasar & 702 \\
\hline Agregat Halus & 858 \\
\hline $\mathrm{NaOH}$ & 117,3 \\
\hline $\mathrm{Na}_{2} \mathrm{SiO}_{3}$ & 117,3 \\
\hline Superplasticizer & 10 \\
\hline
\end{tabular}


TABel 5. Hasil Pengujian Beton Segar

\begin{tabular}{clccc}
\hline Campuran & $\begin{array}{c}\text { Slump flow } \\
(\mathbf{m m})\end{array}$ & $\begin{array}{c}\text { T50 } \\
(\mathbf{s e c})\end{array}$ & $\begin{array}{c}\text { V-funnel } \\
(\mathbf{m m})\end{array}$ & $\begin{array}{c}\text { L-box } \\
(\text { Ratio })\end{array}$ \\
\hline SCGC & 690 & 2,4 & 8,35 & 0,84 \\
\hline Min. & Kriteria Spesifikasi (EFNARC, 2002) \\
Maks. & 650 & 2 & 6 & 0,8 \\
\hline
\end{tabular}

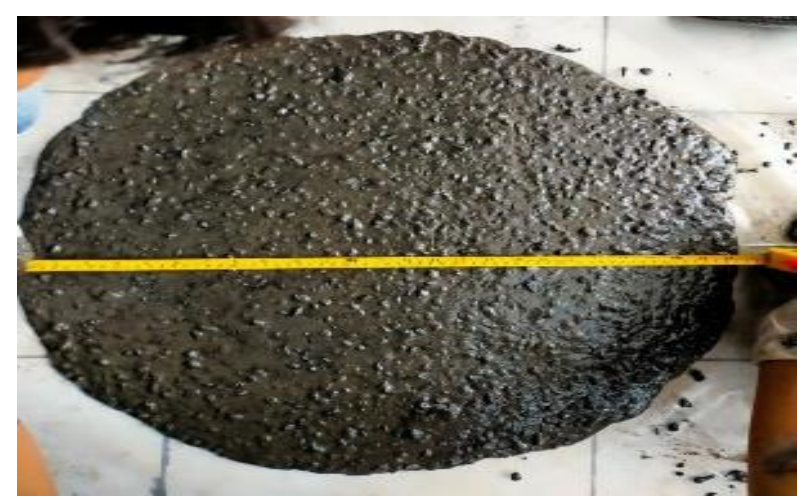

(a)

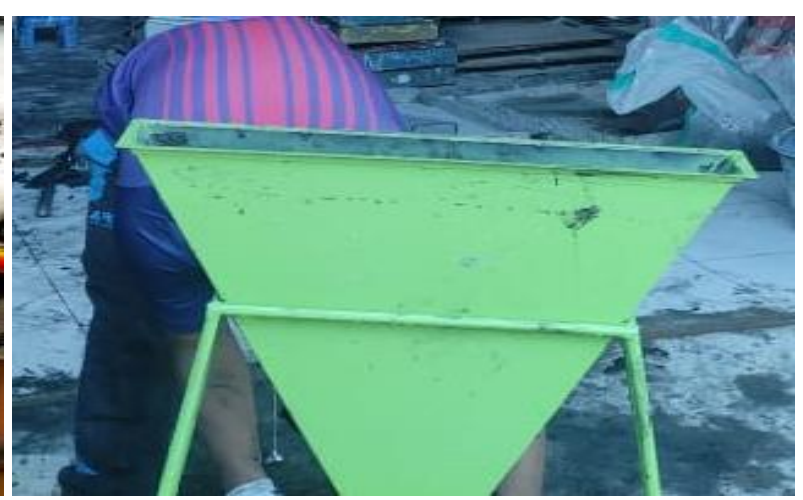

(b)

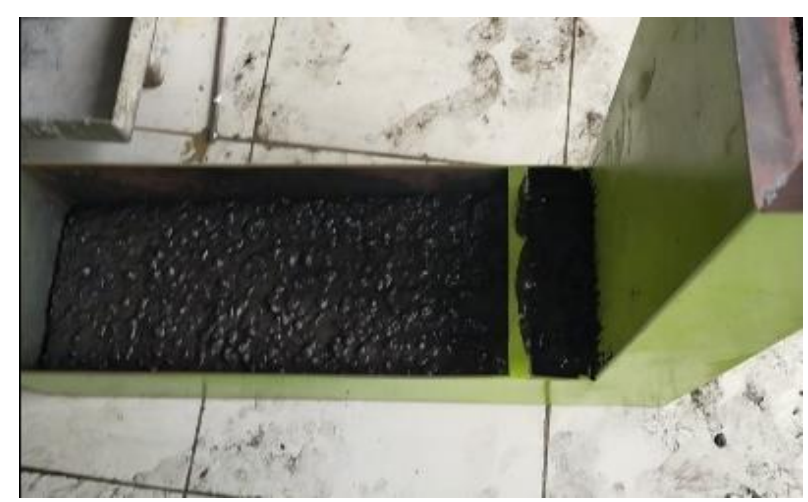

(c)

GAMBAR 3. (a) Slump flow, (b) L-Box, (c) V-funnel

\section{Pengujian Sifat Mekanik}

Penelitian ini dilakukan di Laboratorium Struktur dan Bahan Konstruksi Teknik Sipil Universitas Muhammadiyah Yogyakarta menggunakan universal testing machine untuk menguji kuat tekan, kuat tarik belah, dan kuat lentur pada SCGC. Pengujian dari masingmasing benda uji dapat dilihat pada Gambar 4. Hasil yang diperoleh ditabulasikan dalam Tabel 6 dan hasil keretakan yang diperoleh setelah pengujian dapat dilihat pada Gambar 5. Hasil rata-rata kuat tekan pada penelitian ini sebesar $27,05 \mathrm{MPa}$, kuat tarik belah 6,32 MPa, dan kuat lentur 1,921 MPa. Persentase rasio kuat tarik belah dan kuat lentur sebesar 23,36\% dan $7,10 \%$ dari kuat tekan.

Patel dan Shah (2018) telah melakukan penelitian SCGC dengan curing tanpa oven didapatkan nilai kuat tekan sebesar 20,2 MPa, sedangkan kuat tekan pada penelitian ini diperoleh nilai yang lebih tinggi, yaitu 27,05 MPa. Hal tersebut disebabkan penelitian ini menggunakan curing suhu oven $70^{\circ} \mathrm{C}$. Perlakuan curing dalam oven dibuktikan dapat meningkatkan kuat tekan pada SCGC. 


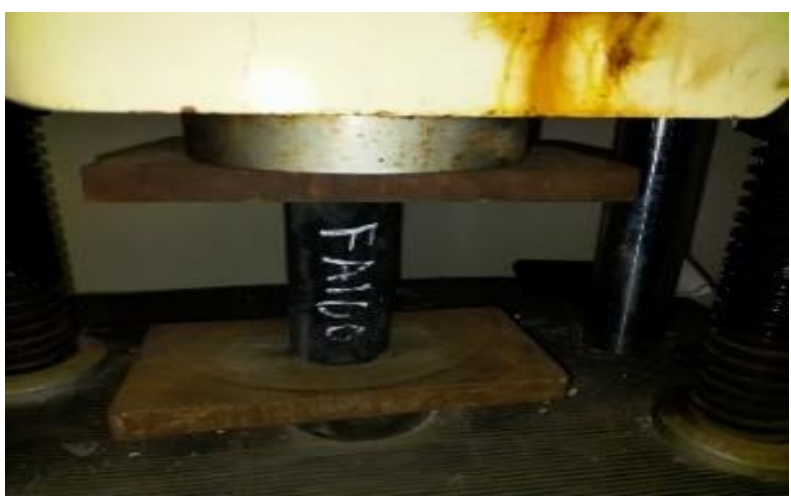

(a)

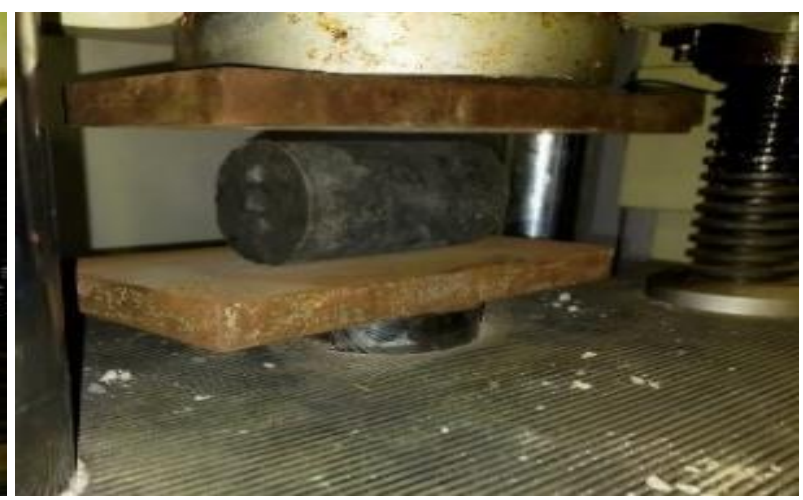

(b)

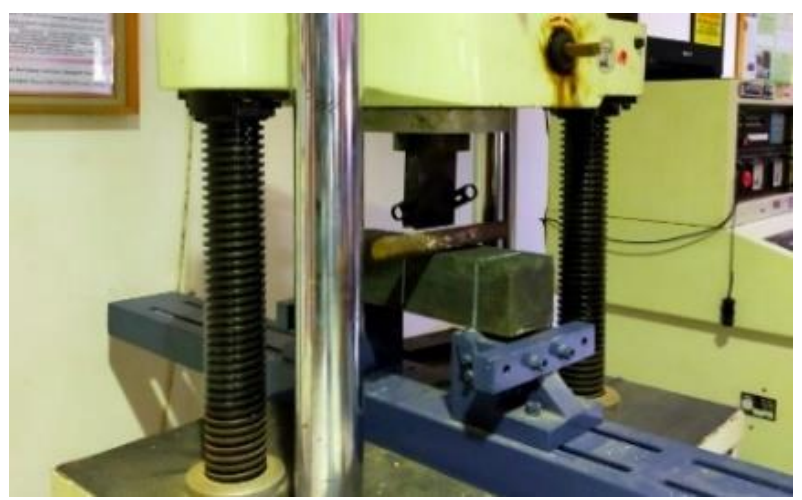

(c)

GAMBAR 4. (a) Kuat tekan, (b) Kuat tarik belah, (c) Kuat lentur

TABEL 6. Hasil Pengujian Beton Segar

\begin{tabular}{cccc}
\hline \multicolumn{4}{c}{ Sifat Mekanik (MPa) } \\
\hline Spesimen & Kuat Tekan & Tarik Belah & Kuat Lentur \\
\hline SCGC 1 & 26,39 & 6,4 & 2,01 \\
SCGC 2 & 27,76 & 7,55 & 1,79 \\
SCGC 3 & 27 & 5,02 & 1,93 \\
Rata-rata & 27,05 & 6,32 & 1,91 \\
\hline
\end{tabular}

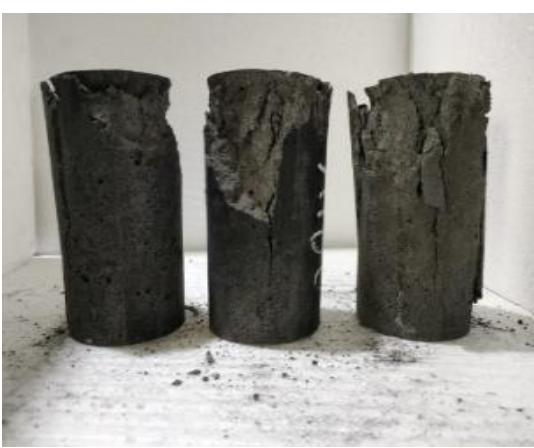

(a)

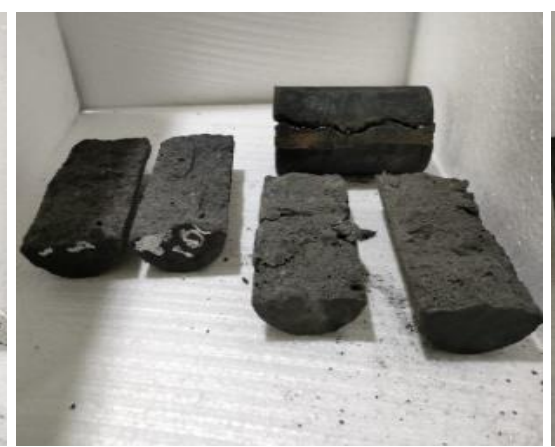

(b)

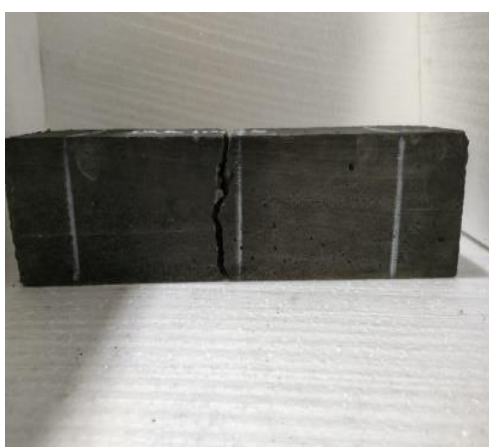

(c)

GAMBAR 5. Hasil Uji Mekanik SCGC

(a) Kuat tekan, (b) Kuat tarik belah, (c) Kuat lentur 


\section{KESIMPULAN}

Self Compacting Geopolymer Concrete (SCGC) merupakan konsep yang relatif baru dan dapat dikatakan sebagai perkembangan konstruksi paling revolusioner di bidang teknologi beton. SCGC adalah jenis beton inovatif yang tidak memerlukan getaran untuk pemadatannya. SCGC juga dapat diproduksi tanpa menggunakan semen sebagai bahan pengikatnya. SCGC dapat digunakan dalam elemen struktur prefabrikasi karena sifatnya yang cepat mengeras.

Berdasarkan hasil pengujian dari ketiga benda uji pada SCGC dapat diambil kesimpulan bahwa kemampuan workability dari SCGC dapat diketahui dengan melakukan pengujian beton segar. Pengujian beton segar pada penelitian ini telah memenuhi persyaratan EFNARC (2002) yang meliputi filling ability, passing ability, dan segregation resistance. Hasil dari slump flow test diperoleh nilai 690 mm dengan T50 adalah 2,4 detik. Hasil dari pengujian $v$-funnel diperoleh nilai $8,35 \mathrm{~mm}$, dan rasio $l$-box test sebesar 0,84 . Setelah dilakukan curing pada SCGC, penelitian ini juga melakukan pengujian mekanik beton berupa kuat tekan, kuat tarik belah, dan kuat lentur. Berdasarkan pengujian yang dilakukan sebanyak tiga kali, diperoleh hasil rata-rata kuat tekan sebesar 27,05 $\mathrm{MPa}$, kuat tarik belah sebesar 6,32 $\mathrm{MPa}$, kuat lentur sebesar 1,91 MPa.

\section{DAFTAR PUSTAKA}

Afriansya, R., Astuti, P., Ratnadewati, V.S., Randisyah, J., Ramadhona, T.Y., \& Anisa, E.A. (2021). Investigation of setting time and flowability of geopolymer mortar using local industri and agriculture waste as precursor in Indonesia. International Journal of Geomate, 21(87), 64-69.

Astuti, P., Rafdinal, R. S., Mahasiripan, A., Hamada, H., Sagawa, Y., \& Yamamoto, D. (2018). Potential development of sacrificial anode cathodic protection applied for severely damaged RC beams aged 44 years. Journal of Thailand Concrete Association, 6(2), 24-31.

Astuti, P., Rafdinal, R. S., Hamada, H., Sagawa, Y., \& Yamamoto, D. (2019). Application of sacrificial anodes cathodic protection for partially repaired RC beams damaged by corrosion. In Proc. 4th Int. Symposium on Concrete and Structures for Next Generation (CSN2019) (pp.284-291).

Astuti, P., Rafdinal, R. S., \& Sagawa, Y. (2020). A study on repairing system of severely damaged $\mathrm{rc}$ beam by cathodic protection using a different kind of sacrificial anodes. Advances in Construction Materials Proceedings of the ConMat'20.

Astuti, P., Kamarulzaman, K., \& Hamada, H. (2021). Non-destructive investigation of a 44-year-old RC structure exposed to actual marine tidal environments using electrochemical methods. International Journal of Integrated Engineering, 13(3), 148-157. Retrieved from https://publisher.uthm.edu.my/ojs/index. php/ijie/article/view/8918

Ardiantoro, D., Sunnarsih, E. S., \& Sucipto, T. L. A. (2021). The role of rice husk ash in enhancing the fresh properties, density, and compressive strength of fly ash based self compacting geopolymer concrete. Journal of Physics: Conference Series, 1808(1), 1-10.

ASTM C618-92a. (1994). Standard specification for fly ash and raw or calcinated natural pozzolan for use as mineral admixture in Portland cement concrete. Annual book of ASTM Standards, 4(2).

Chatam House. (2018). Making Concrete Change Innovation in Low-Carbon Cement and Concrete. London: The Royal Institute Affairs.

EFNARC. (2002). Specification and guidelines for self compacting concrete. London, UK:Association house.

Ekaputri, J. J., \& Bari, M. S. A. (2020). Perbandingan regulasi fly ash sebagai limbah B3 di Indonesia dan beberapa negara. Media Komunikasi Teknik Sipil, 26(2), 150-162. https://doi.org/10.14710/mkts.v26i2.307 62

Gulsan, M. E., Alzeebare, R., Rasheed, A. A., Nis, A., \& Kurtoglu, A. E. (2019). Development of fly ash/slag based self compacting geopolymer concrete using nano silica and steel fiber. Construction 
and Building Materials, 211, 271-283. https://doi.org/10.1016/j.conbuildmat.20 19.03.228

Husein, G. F., Ismail, M., Khalid, N. H. A., Hussin, M. W., \& Mirza, J. (2018). Compressive strength and microstructure of assorted wastes incorporated geopolymer mortars: Effect of solution molarity. Alexandria Engineering Journal, 57(4), 3375-33386. https://doi.org/10.1016/j.aej.2018.07.011

Irlan, A. E., Kurniawati, G., \& Sofyan, M. (2020). Tinjauan karakteristik bahan penyusun beton berpori dengan penggunaan fly ash dan superplasticizer untuk perkerasan jalan ramah lingkungan, KILAT, 9(2), 244-256. https://doi.org/10.33322/kilat.v9i2.954

Kamarulzaman, K., Astuti, P., Caronge, M. A., Nguyen, L., \& Sagawa, Y. (2020). Combination of impressed current and sacrificial anode cathodic prevention to improve corrosion prevention system in reinforced concrete. Advances in Construction Materials Proceedings of the ConMat'20.

Paramitha, D. R., Meok, L. Y., Hardjito, D., \& Antoni, A. (2017). Pengaruh kombinasi semen fly ash dan variasi water content dengan penambahan superplasticizer terhadap kepadatan pasta. Jurnal Dimensi Pratama Teknik Sipil, 6(2), 5663.

Patel, Y. J. \& Shah, N. (2018). Development of self compacting geopolymer as a sustainable construction material. Sustainable Environment Research, 28(6), 412-421. https://doi.org/10.1016/j.serj.2018.08.00 4

Praveen, P. U., \& Srinivasan, K. (2017). Self compacting geopolymer concrete a review. IOP Conference Series: Materials Science and Engineering, 263(3), 1-9.

Rawi, S. A., \& Taysi, N. (2018). Perfomance of self compacting geoplymer concrete with and without GGBFS and steel fiber. Advanced in Concrete Construction, 6(4), 323-344.

https://doi.org/10.12989/acc.2018.6.4.32 3
Reddy, K. M. \& Kumar, G. N. (2017). Experimental study on self compacting geopolymer concrete. International Research Journal of Engineering and Technology, 4(1), 953-957.

Republik Indonesia. (2014). Peraturan Pemerintah Republik Indonesia Nomor 101 Tahun 2014 tentang pengelolaan limbah berbahaya dan beracun. Jakarta: Pemerintah Republik Indonesia.

Republik Indonesa. (2021). Peraturan Pemerintah Republik Indonesia Nomor 22 Tahun 2021 tentang penyelenggaraan perlindungan dan pengelolaan lingkungan hidup. Jakarta: Pemerintah Republik Indonesia.

Vinothkumar, A., Kalaivani, M., \& Easwaran, P. (2019). Development of fly ash GGBS based self compacting geopolymer concrete: A review. International Research Journal of Multidisciplinary Technovation, 1(6), 373-377. https://doi.org/10.34256/irjmtcon49

PENULIS:

Evelyn Anabela Anisa

Program Studi Teknik Sipil, Fakultas Teknik, Universitas Muhammadiyah Yogyakarta. Jalan Brawijaya, Tamantirto, Kasihan, Bantul.

Email: evelyn.anabela.ft18@mail.umy.ac.id

Rahmad Afriansya

Program Studi Teknik Sipil, Fakultas Teknik, Universitas Muhammadiyah Yogyakarta. Jalan Brawijaya, Tamantirto, Kasihan, Bantul.

Email: rahmad.a.ft17@mail.umy.ac.id

Julian Randisyah

Program Studi Teknik Sipil, Fakultas Teknik, Universitas Muhammadiyah Yogyakarta. Jalan Brawijaya, Tamantirto, Kasihan, Bantul.

Email: julian.r.ft18@mail.umy.ac.id

Pinta Astuti

Program Studi Teknik Sipil, Fakultas Teknik, Universitas Muhammadiyah Yogyakarta. Jalan Brawijaya, Tamantirto, Kasihan, Bantul.

Email: pinta.astuti@ft.umy.ac.id 